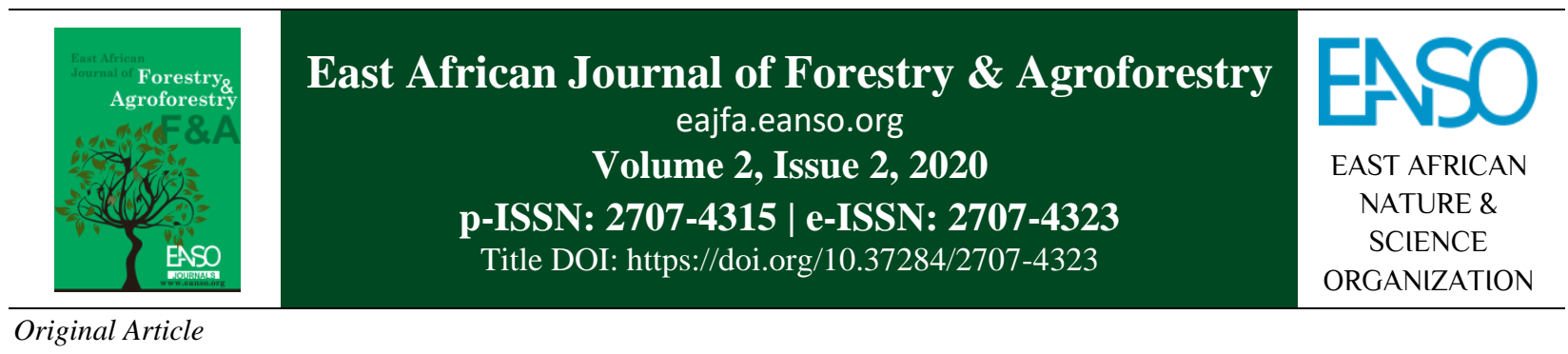

\title{
Floricultural Methods of Propagation and Challenges Facing Practitioners in Jimeta and Yola Metropolis of Adamawa State Nigeria
}

\author{
Enoch Buba Badgal ${ }^{1}$, David Cromwell Sakiyo ${ }^{2 *}$, \\ Kenas Suleiman Hamman ${ }^{3}$ \& Adamu Bappa Magaji \\ ${ }^{1}$ Department of Forestry Technology, Adamawa State Polytechnic, Adawama State, Yola, Nigeria. \\ ${ }^{2}$ Department of Forestry Technology, Adamawa State College of Agriculture Ganye, Adawama State, Nigeria. \\ ${ }^{3}$ Department of Science Laboratory Technology, Adamawa State Polytechnic, Adawama State, Yola, Nigeria. \\ ${ }^{*}$ Author for Correspondence email: dsakiyo1@ gmail.com
}

Article DOI: https://doi.org/10.37284/eajfa.2.2.207

\section{Article history: ABSTRACT}

09 September 2020

Floriculture as a field of science deals with production, use, marketing and management of ornamental plants. This article examines floricultural

Keywords: propagation methods used by florists in the two towns (Jimeta and Yola) that formed Adamawa State capital. A total of 25 florists were purposively selected

Floricultural,

Challenges,

Ornamental,

Florists,

Plants,

Practitioners. for the research and face to face interviewed using well-structured questionnaires. A total of 31 ornamentals plants species in the gardens of the florists were considered for the research. Both descriptive and inferential statistics were adopted for analysis of the data collected. The results revealed that florists preferred the use of seeds, stem cutting, rhizoids, tufts, and roots for the propagation of ornamentals. Results of challenges facing florists indicated that water, land to operate, credit facility, high cost of nursery implements, pest and disease control recorded lower confidence of variation in the response spread of the florists which are indications of acute problems. More sensitization on floriculture need be done to attract more women into the business and florists should go for training to improve their skills and organize cooperative groups to seek support from any institution that may be ready to help.

\section{APA CITATION}

Badgal, E., Sakiyo, D., Hamman, K., \& Magaji, A. (2020). Floricultural Methods of Propagation and Challenges Facing Practitioners in Jimeta and Yola Metropolis of Adamawa State Nigeria. East African Journal of Forestry and Agroforestry, 2(2), 16-23. https://doi.org/10.37284/eajfa.2.2.207 


\section{CHICAGO CITATION}

Badgal, Enoch, David Sakiyo, Kenas Hamman, and Adamu Magaji. 2020. "Floricultural Methods of Propagation and Challenges Facing Practitioners in Jimeta and Yola Metropolis of Adamawa State Nigeria". East African Journal of Forestry and Agroforestry 2 (2), 16-23. https://doi.org/10.37284/eajfa.2.2.207.

\section{HARVARD CITATION}

Badgal, E., Sakiyo, K., Hamman, C., and Magaji, A. (2020) "Floricultural Methods of Propagation and Challenges Facing Practitioners in Jimeta and Yola Metropolis of Adamawa State Nigeria", East African Journal of Forestry and Agroforestry, 2(2), pp. 16-23. doi: 10.37284/eajfa.2.2.207.

\section{IEEE CITATION}

E. Badgal, D. Sakiyo, K. Hamman, and A. Magaji, "Floricultural Methods of Propagation and Challenges Facing Practitioners in Jimeta and Yola Metropolis of Adamawa State Nigeria”, EAJFA, vol. 2, no. 2, pp. 16-23, Sep. 2020.

\section{MLA CITATION}

Badgal, Enoch, David Sakiyo, Kenas Hamman, and Adamu Magaji. "Floricultural Methods of Propagation and Challenges Facing Practitioners in Jimeta and Yola Metropolis of Adamawa State Nigeria". East African Journal of Forestry and Agroforestry, Vol. 2, no. 2, September 2020, pp. 16-23, doi:10.37284/eajfa.2.2.207.

\section{INTRODUCTION}

Floricultural science is a discipline in agriculture that deals with the practice of growing, harvesting, marketing, Storing, designing, maintenance and utilization of ornamental plants by humans This Involves intensive production of flowers, shrubs, trees, bulbs and ground cover tufts (Muthoka \& Muritihi, 2008; Sani et al., 2016). Floricultural plants are classified into two major types namely, the indoor and outdoor-grown ornamental plants. These classifications are based on their modes and characteristics that determine where they are to be planted and the purposes of planting. In Ahmadu Bello University, Zaria, Nigeria results of floristic research have shown that out of 68 plant species on the main campus, 27 species were under indoor grown, 16 species were shade-providing plants and 22 species were hedges and three species were grouped under lawns (Sani et al., 2016). The classifications are based on characteristics which include features like their heights, shapes, colours, sizes, the arrangement of flowers and leaves, beautiful orientation or aesthetic nature of the plants and fragrance produced and other benefits obtained like fruit, ability to sequester greenhouse gases, control of noise pollution and provision of herbal therapies (Agyekum, 2010; Okeke, 2017). The common ornamental plants grown in public landscapes include croton species, palms, black currant, lantana grass, carpet grass, anti-snake plants, Aloe vera, dumb cane, roses, Acalypha, Ficus species, green bush, cactus species, Ixora, lemongrass, euphobia species, thuja, hibiscus etc. (Okeke, 2017).

Worldwide today people love to live in a serene and beautiful environment decorated with admiring flowers and other ornamental species. This aroused the interest of gardeners to grow new varieties of ornamental plants with unique features even grown for social status and admiration (Emokoro et al., 2014). The integration of floristic plants into public landscapes has brought a lot of socio-economic, health, nutrition, mental, psychological benefits to humans (Okeke, 2017). These benefits include well decorated and scenic residential areas, creation of walking and parking lots, screening of places driving guides and demarcation of places (Amingad \& Laksmipathy, 2014). Several studies have shown that both indoor and outdoor-grown ornamentals provide regulatory ecosystem services ranging from sequestration of greenhouse gases to empty the atmosphere of toxic gaseous substances, noise pollution, provision of shades for resting during sunny days, production of fragrance and repellents of harmful insects and reptiles especially some snakes in human habitation (Sani et al., 2016; Agyekum, 2010; Okeke, 2017). In offering provisioning ecosystem services, the outgrown ornamentals also provide edible fruits, medicinal properties and fuelwood at an older age (Okeke, 2017).

In Nigeria, agriculture provides a means of sustainable livelihoods for over $70 \%$ of the National Population Commission (NPC, 2006). Ornamental plant industries have potentials for the 
generation of employment for both urban and rural dwellers directly or indirectly (Usman et al., 2002; Hokayode et al., 2008). These jobs include labour jobs, like nursery manager, individual cultivation and marketing of seedlings. In Nigeria, this has led to springing up of the industries along major roads, highways, footpaths, public and private places. These have created opportunities for beginners or even full-time employment for sustainable livelihoods (Emokoro et al., 2014).

Plant propagation is the process of producing new plants from existing ones. it is both art and science that require knowledge, skill, dexterity and experience to record success. Plant propagation can be broadly classified in two namely sexual and asexual. Sexual reproduction involves the production of offspring (seed) by fertilization of male and female gametes. This method preserves vigorous hybrids and improves the genetic potentials of the plant to adapt to environmental pressures (Moore \& Bradley, 2018). The asexual method involves using vegetative parts of a single plant to produce new ones. This includes parts of plants like stems, suckers, stolon, corms, plantlets, roots and leaves. The popular techniques like stem cutting, grafting, suckering, budding and air layering are practised by many floriculturists around the globe. These asexual methods are widely used in floristic business today because of their easier ways of production provide faster growth (Arbury, 1997). Examples of both sexual and asexual methods employed for the production of specific aesthetic plants today include use of seeds for species like king palms, black currant, grasses and African daily while croton, euphorbia, Ixora, Ficus, Acalypha species are mostly produced through stem cutting and for other decorative plants like Cycads, snake plants and Banana plantlets and suckers are used (Arbury, 1997; Sani et al., 2016).

Floricultural practice like any other business around the world is also having its challenges that can cause serious setbacks in production and income generation for sustainable livelihoods of the Practitioners. Findings from researches have revealed that in Ghana a large number of ornamental producers have difficulty in getting planting materials and they have to rely on fellow farmers for successful operations (Emokoro et al., 2014). Buttressing this fact research conducted on the challenges facing floriculture practice indicated that in eight cities (Kano, Jos, Makurdi, Katsina, Benin, Ibadan. Abuja and Uyo) of Nigeria, florists have problems of scarcity of water during dry seasons, lack of basic nursery and credit facilities from government and financial Institutions and serious pests and disease infestations experienced (Akintoye et al., 2011). In Akure Nigeria, it was revealed that the study carried on the contribution of some ornamental plants to the socio-economic development of urban households recorded that $38 \%$ for inadequate land, $52 \%$ for pest attack and $10 \%$ for water problems respectively. Major challenges of the florists in the city and other minor ones included the age of the operators and the lack of organized cooperative groups (Adeduntan, 2015). In US ecological studies have revealed that more than $50 \%$ of all invasive non-woody plant species and $85 \%$ of invasive woody plant species were originally introduced by plants used as ornamentals and other landscape purposes causing $£ 35$ billion annual loss in her economy (Li et al., 2006). Other negative effects of exotic ornamental species documented were the widespread replacement of millions of acres of native vegetation with primarily non-native species in merged landscapes constituted growing problem to organisms that depend on native plants for food, shelter and breeding spaces (Wilde et al., 2015). This study examines floricultural propagation methods used by florists in two towns (Jimeta and Yola) that formed Adamawa State capital.

\section{MATERIALS AND METHODS}

\section{Description of the Study Area}

The study area covered Jimeta and Yola town that formed the capital city of Adamawa State popularly known as Yola situated in the North-eastern part of Nigeria. Iimeta and Yola town belong to Yola North and Yola South Local Government Areas laying on latitude $9^{0} 17^{\prime} 13$ North and longitude $12^{0}$ 29’3 East. 
Figure 1: Map of the Study Area

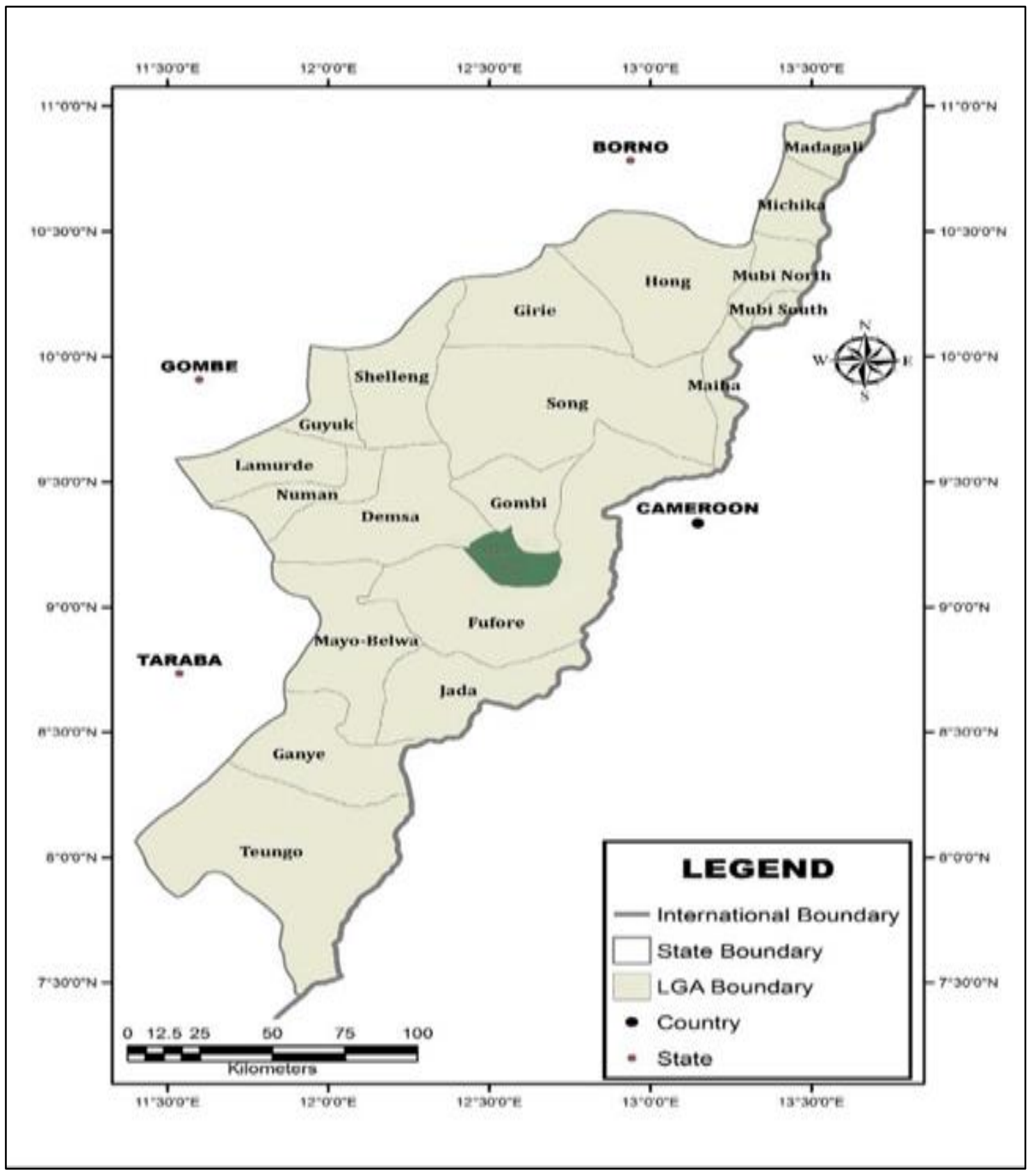

\section{The Methods of Data Collection}

The method of data collection adopted for this research was the survey method. Twenty-five florists that constituted sample size for the study were purposively selected as described by Idris et al., (2013) from Jimeta and Yola town that formed the capital city of Adamawa States.
The instrument adopted for sourcing data during this research was the use of a well-structured questionnaire. The twenty-five questionnaires produced were personally administered to the respondents (florists) through face to face interviews in their respective gardens. The responses were assessed using a five-point Likert scale (strongly agreed $=\mathrm{SA}$, agreed $=\mathrm{A}$, undecided=UD, disagreed=DA, strongly disagreed $=\mathrm{SD}$ ). 


\section{Statistical Analysis}

The data obtained were analysed using simple descriptive and inferential statistics. Data collected on demography, methods of ornamental plant production were analysed by a simple percentage (Usman et al., 2014) while challenges facing floriculture were analysed using standard deviation.

\section{RESULTS AND DISCUSSION}

\section{Respondents Demographic Information}

The demographical data collected comprised of gender, staff training, age and level of education. Majority of the respondents (96\%) were male while only $4 \%$ of the respondents were female. This indicated poor participation of women in the floriculture business in the study area. On technical training, only $8 \%$ of the twenty-five respondents were technically trained under ideal training but the remaining 92\% learned the work on the course of doing the job. The respondents with 1-5 experience and 11-15 years of experience constituted $20 \%$ each of the respondents while respondents with 6-10 and 16-20 years of experience formed $36 \%$ and $16 \%$ of the florists respectively while the respondents with 31 years of experience and above recorded only $8 \%$. There were no florists with years of experience that ranged from 21-25 and 26-30. This shows that only a few of the practitioners have spent many years gaining experience on the job. The level of education shown suggested that majority of the respondents were holders of the senior secondary certificate (SSCE) which constituted $64 \%$ of the respondents followed by respondents with the first school leaving certificate (FSLC) while those with informal education, National Diploma (ND), Higher National Diploma/ Degree and National Certificate of Education (NCE) recorded 16\%, 8\%, $8 \%, 4 \%$ and $0 \%$, respectively.

\section{Methods of Propagation}

Table 1 shows different methods used in the propagation of thirty-one ornamental plant species considered for this study. The table unfolds that twelve plant species were propagated one hundred percent using seeds. These species include palm oil, lady palm, flamboyant tree, manila palm, coconut palm, masquerade, mandarin orange, date palm, mahogany, black currant, neem tree, mango tree, while sunflower recorded $96 \%$ of respondents' endorsement as propagated by seeds, lantana bush, anti-snake plant, ice plant, green bush, thuja and coleus species recorded 4\%. Table 1 shows that the florists in the study area used rhizoids, roots and tuft as means of propagation, indicating one hundred percent response for carpet grass, and Aloe vera while $96 \%$ for port Harcourt grass, coleus and ice plant each, 92\% for elephant grass and ice plant followed by $8 \%$ rose plant and $4 \%$ lantana bush, queen of the night and sunflower respectively (Sani et al., 2016).

Stem cutting from the same table is another widely used method of ornamental plants propagation in the study area, Ixora, Acalypha, TMC, Christmas tree and yellow bush (croton) recorded one hundred percent response while green bush, queen of the night, Thuja, hibiscus and anti-snake plant recorded $96 \%$ response, followed by $92 \%$ each for rose flower and lantana bush, $8 \%$ for elephant grass and $4 \%$ for Port Harcourt grass respectively (Table 1). These findings are in consonance with the findings of Sani et al., (2016) on methods of ornamental plant propagation. The other methods like budding, air layering and tissue culture are not used by florists in the study area as clearly indicated in the table above. This could be as a result of poor knowledge, lack of facilities and inadequate technical persons (Akintoye et al., 2011). 
Table 1: Methods of Propagation used by the Florists

\begin{tabular}{|c|c|c|c|c|c|c|c|c|}
\hline $\begin{array}{l}\text { Plant Species } \\
\text { Scientific Name }\end{array}$ & Common Name & Seed $(\%)$ & $\begin{array}{l}\text { Rhizoid / Root/ } \\
\text { Tuft (\%) }\end{array}$ & $\begin{array}{l}\text { Stem } \\
\text { cutting }\end{array}$ & Budding & $\begin{array}{l}\text { Tissue } \\
\text { Culture }\end{array}$ & $\begin{array}{l}\text { Air } \\
\text { laying }\end{array}$ & Suckers \\
\hline Thuja occidentalis & Thuja & & - & 96 & - & - & - & - \\
\hline Acalypha wilkesiana & Acalypha & - & - & 100 & - & - & - & - \\
\hline Ixora oceanna & Ixora & - & - & 100 & - & - & - & - \\
\hline Tabernaemontana divavicala & Grape jasmine & - & - & 100 & - & - & - & - \\
\hline Paspalum spp. & Port Harcourt grass & - & 96 & 4 & - & - & - & - \\
\hline Ribes nigrum & Blackcurrant & 100 & - & - & - & - & - & - \\
\hline Mangifera indica & Mango tree & 100 & - & - & - & - & - & - \\
\hline Axonopus compressus & Carpet grass & - & 100 & - & - & - & - & - \\
\hline Rosa spp. & Rose flower & - & 8 & 92 & - & - & - & - \\
\hline Azadirachta indica & Neem tree & 100 & - & & - & - & - & - \\
\hline Polyalthia longifolia & Masquerade plant & 100 & - & - & - & - & - & - \\
\hline Sansevieria trifasciata & Snake plant & 4 & - & 96 & - & - & - & - \\
\hline Hibiscus rosa-sinensis & Chinese Hibiscus & - & - & 100 & - & - & - & - \\
\hline Lantana camara & Lantana bush & 4 & 4 & 92 & - & - & - & - \\
\hline Khaya senegalensis & Mahogany & $321^{\prime}$ & - & - & - & - & - & - \\
\hline Cestrum nocturnum & Queen of the night & - & 4 & 96 & - & - & - & - \\
\hline Cocos nucifera & Coconut palm tree & 100 & - & - & - & - & - & - \\
\hline Aloe vera & Aloe vera & - & 100 & - & - & - & - & - \\
\hline Phoenix dactylifera & Date palm & 100 & - & - & - & - & - & - \\
\hline Carpobrotus spp & Ice plant & 4 & 96 & - & - & - & - & - \\
\hline Atheris chlorechis & Green bush & 4 & & 96 & - & - & - & - \\
\hline Coleus spp. & Coleus & 4 & 96 & - & - & - & - & - \\
\hline Helianthus spp. & Sunflower & 96 & 4 & - & - & - & - & - \\
\hline Pennisetum & Elephant grass & - & 92 & 8 & - & - & - & - \\
\hline Codiaeum variegatum & Croton yellow bush & - & - & 100 & - & - & - & - \\
\hline Elaeis guineensis & Palm oil & 100 & - & - & - & - & - & - \\
\hline Rhapis excelsa & Lady palm & 100 & - & - & - & - & - & - \\
\hline Delonix regia & Flamboyant & 100 & - & - & - & - & - & - \\
\hline Veitenia merrillii & Manila palm & 100 & - & - & - & - & - & - \\
\hline Pinus spp. & Christmas tree & & & 100 & - & - & - & - \\
\hline Citrus reticulata & Mandarin orange & 100 & - & - & - & - & - & - \\
\hline
\end{tabular}


Table 2 shows the standard deviation analysis of the challenges facing the florists in the study area. The critical mean to determine the deviation of the sample population was 2.5 which means that all the challenges are capable of causing problems at a certain level to the operations of the florists in the study area since their means ranged from 2.84-4.88 (Akintoye et al., 2011; Emokoro et al., 2014). The table also indicates that the lower coefficient of variation $(\mathrm{CV})$ percentages or relative standard deviation of $6.79 \%, 12.96 \%, 16.38 \%, 17.34 \% 21$. $32 \%$ and $21.96 \%$ respectively for lack of credit facility, water scarcity difficulty in pest and disease control, getting seeds, competition among operators and difficulty in getting garden soil for nursery, constitute more serious problems to the florist's operations than other challenges (Table 2). This is as a result of a lower $\mathrm{CV}$ which shows a more uniform agreement or acceptance level by more respondents (florists) than others on the list of the challenges provided. This discovery is in line with the findings that lack of land space, pest attack, water problem, lack of credit facility and cooperative groups are major impairments to floricultural development in many cities of Nigeria (Akintoye et al., 2011; Adedutan, 2015).

Table 2: Challenges Facing Floricultural Practice in Study Area

\begin{tabular}{lllllllll}
\hline Challenge & SA & A & U & D & SD & MEAN & SD & CV (\%) \\
\hline Water scarcity & 14 & 10 & 1 & 0 & 0 & 4.52 & 0.585947 & 12.96 \\
Poor patronage & 2 & 14 & 5 & 2 & 2 & 3.48 & 0.964365 & 27.71 \\
Lower Price & 1 & 5 & 9 & 9 & 1 & 2.84 & 0.796869 & 28.06 \\
Lack of land to operate & 12 & 9 & 3 & 1 & 0 & 4.28 & 0.749444 & 17.51 \\
Lack of skilled manpower & 2 & 10 & 2 & 5 & 6 & 2.88 & 1.336039 & 46.39 \\
Lack of financial empowerment & 22 & 3 & 0 & 0 & 0 & 4.88 & 0.331662 & 6.79 \\
Difficulty in accessing seed & 5 & 15 & 1 & 4 & 0 & 3.84 & 0.665833 & 17.34 \\
High competition among producers & 0 & 13 & 9 & 2 & 1 & 3.36 & 0.716473 & 21.32 \\
High cost of transportation & 4 & 11 & 7 & 2 & 1 & 3.6 & 0.903696 & 25.10 \\
High cost of packaging materials & 5 & 16 & 1 & 1 & 2 & 3.84 & 1.014068 & 26.41 \\
Insufficiency of green implements & 3 & 14 & 2 & 1 & 5 & 3.36 & 1.323505 & 39.39 \\
Difficulty in getting fertilizers & 2 & 9 & 4 & 7 & 3 & 3 & 1.099242 & 36.64 \\
Difficulty in getting garden soil & 10 & 12 & 1 & 1 & 1 & 4.16 & 0.913783 & 21.96 \\
Pests and disease control & 2 & 15 & 6 & 2 & 0 & 3.68 & 0.602771 & 16.38 \\
\hline
\end{tabular}

\section{CONCLUSION}

It can be established that florists in Adamawa State metropolis are mostly men, untrained and only a few have many years of practice. The florists used seeds, stem cutting and rhizoids/roots in producing ornamental plant seedlings and never explored other methods like air layering, tissue culturing and budding. Florists faced major challenges in the area of credit facility, water scarcity, garden implements, difficulty in pest, disease control, getting seeds. More enlightenment needs to be made for better participation of women in floriculture in Adamawa State.

\section{ACKNOWLEDGEMENT}

On behalf of all the co-authors of this article, I wish to appreciate Mr. Amdzanda Moses who analysed the data for us, acting director of works in the person of Mr. Sani Mohammed and Mr. Anthony Teri a security man for allowing us to write this article in the works unit during the lockdown as a result of CO-VID 19 pandemic.

\section{REFERENCES}

Adeduntan, S. A. (2015). Contribution of some ornamental plants to the socio-economic development of urban household in Akure metropolis. African Journal of Agricultural Research, 10(4), 264-268. 
Agyekum, N. (2010). Plant Science 211, Fall 2010: Uses of ornamental plants. Retrieved from the North Dakota State University at https://www.ndsu.edu/pubweb/chiwonlee/plsc 211/student\%20papers/article10/Agyekum,\%2 0Nana\%20Akua/characteristics.html.

Akintoye, H. A., Idowu, O. O., Olufolaji, A. O., Adebayo, A. G., Olatunji, M. T., Aina, O. O., \& Shokalu, A. O. (2011). Prospects and challenges of floriculture business in Nigeria. European Journal of Social Sciences, 19(3).

Amingad, V. \& Lakshmipathy, M. (2014). Ornamental plants and their roles in human psychology. $2^{\text {nd }}$ International Conference on Agricultural \& Horticultural Sciences. Hyderabad, India: Agrotechnol

Arbury, J. (1997). The complete book of plant propagation. Taunton Press.

Emokoro, C. O., Alufobai, G. O. \& Ogbeni, G. L. (2014). Analysis of ornamental plant production in Edo and Delta States, Nigeria. Applied Tropical Agriculture, 1-5.

Fakayode, B. S., Adewumi, M. O., Rahji, M. A. Y., \& Jolaiya, J. A. (2008). Viability and resource use in ornamental plants nursery business in Nigeria. European Journal of Social Sciences, 6(4), 19-28.

Idris, S., Farida, S., Sambo, M. U., Garba, M. I., \& Dambatta, M. A. (2013) Effect of forest fire on wildlife species at Yankari Game Reserve. Proceeding of the $37^{\text {th }}$ annual conference of the forestry association of Nigeria (pp. 357-358). Held in Uyo, Akwa Ibom State, Nigeria $4^{\text {th }}-9^{\text {th }}$ November, 2013.

Li, Y., Cheng, Z., Smith, W., Ellis, D., Chen, Y., Lu, L., ... \& Zheng, X. (2006). Problems and challenges of invasive ornamental plants and molecular tools to control their spread. Journal of Crop Improvement, 17(1-2), 279-301.

Moore, K. A. \& Bradley, L. K. (Eds). (2018). North Carolina Extension Gardener Handbook. University of North Carolina Press
Muthoka, N. M., \& Muriithi, A. N. (2006, August). Smallholder sum+mer flower production in Kenya: A myth or a prospect? In XXVII International Horticultural CongressIHC2006: International Symposium on Ornamentals, Now! 766 (pp. 219-224).

National Population Commission (NPC). (2006). Provisional population figures: Available at http://www.nigeriastate.gov.ng/ National Bureau of Statistics Office Gazette (fgp71) 520071-500 (124)

Okeke, N. (2017, Jul 25). 20 commonly grown flowers in Nigeria. Retrieved from Connect Nigeria at https://connectnigeria.com/articles/2017/07/20 -commonly-grown-flowers-in-nigeria/

Sani, Y., Babaj, B. A., Barnabas, S., Isah, A., Yahaya, R. A. \& Hassan, M. B. (2016). Identification and description of some common ornamental plants in Abu Zaria, Nigeria. Advances in Nutrition \& Food Science, 1(1), 15.

Usman, J. M., Abiola, I. O., Adesope, A. A. A., \& Adeoye, O. (2002). Floricultural business; panacea to poverty eradication. In $A$ paper presented at the proceedings of Annual Conference of Horticultural Society of Nigeria.

Usman, J.M., Alhonsu, J.O.Y., Idowu, O.A. and Egbewole, Z.T. (2014) Marketing analysis of rattan (Daemonorops draco) products in Ijebu Ode Local Government Area of Ogun State, Nigeria. Proceeding of the $37^{\text {th }}$ Annual Conference of the Forestry Association of Nigeria (pp. 546-548). Minna, Niger State.

Wilde, H. D., Gandhi, K. J., \& Colson, G. (2015). State of the science and challenges of breeding landscape plants with ecological function. Horticulture research, 2(1), 1-8. 